\title{
3 Research Suare \\ Protist diversity and community complexity in the switchgrass rhizosphere are dynamic
}

Javier A. Ceja-Navarro

Yuan Wang

Daliang Ning

Abelardo Arellano

Leila Ramanculova

Mengting Yuan

Alyssa Byer

Kelly D. Craven

Malay C. Saha

Eoin L. Brodie

Jennifer Pett-Ridge

Mary K. Firestone

\section{Video Byte}

Keywords: soil protists, soil microbiome, switchgrass, rhizosphere, community assembly, soil, protist, Microbiome, community, bacteria, development

Posted Date: October 14th, 2021

DOl: https://doi.org/10.21203/rs.3.rs-968278/v1

License: (c) (i) This work is licensed under a Creative Commons Attribution 4.0 International License.

Read Full License 


\section{Abstract}

Plants evolved in a world dominated by prokaryotic and eukaryotic microbes. Underneath the surface, plant roots interact with microbes in the soil - the rhizosphere microbiome. But although bacteria and fungi are well-studied in the rhizosphere, other components, including viruses and protists, are less well understood. To better understand the extent to which biological and environmental factors shape protist communities, researchers analyzed protist communities associated with the rhizosphere and bulk soil of switchgrass plants in different developmental stages. They found that the diversity of protists was lower in the rhizosphere than in the bulk soil and that the composition of protist communities changed through the different phenological stages of the plant. Patterns of prevalent protist groups revealed that while most protists changed in abundance during plant growth stages, some plant pathogenic protists and omnivorous protists reoccurred at many stages of development, and protists co-occurrence networks were more complex in the rhizosphere than in the bulk soil. Protist community assembly was mainly controlled by homogenous selection and dispersal limitation. These results demonstrate that as bacteria do, protists also respond to changes in the environment around plants' roots. Improving our understanding of patterns in rhizosphere-associated protist communities will help to shed light into the root-microbe-soil ecosystem. 